\title{
AZ ELMÚLT TíZ ÉV KUTATÁSI EREDMÉNYEI A FELSŐOKTATÁSI HALLGATÓK ÖNKÉNTESSÉGÉRŐL
}

\author{
FÉNYES HAJNALKA ${ }^{1}$
}

DOI: https://doi.org/10.53585/OnkSzem.2021.1.56-68

\section{Absztrakt}

CHERD-Hungary kutatóközpont 2010 óta követi nyomon a felsőoktatási hallgatók önkéntességét és önkéntes csoporttagságait a történelmi, partiumi régióban (Kelet-Magyarország, Erdély partiumi része, Kárpátalja). A minta 2019-ben tovább bővült néhány felvidéki és vajdasági intézménnyel is. Az $1500-$ 3000 fős minták legalább fele magyarországi diák volt. Tanulmányunkban az elmúlt tíz év kutatási eredményeit mutatjuk be az első Nemzeti Önkéntes Stratégiára (2012-2020) is reflektálva. A 2019-ben mért magyarországi eredmények már tükrözik a középiskolákban bevezetett Iskolai Közösségi Szolgálat hatását is, mivel a felsőoktatásban 2016 után jelent meg az első olyan évfolyam, akik már részt vettek a programban. A tanulmány bevezető részében a felsőoktatási hallgatók önkéntességének trendjeiről lesz szó 2010 és 2019 között, majd kitérünk az önkéntesség definíciós kérdéseire. Itt két kritériumra reflektálunk: a kötelező/nem kötelező és a mások és/vagy önmaga számára hasznos dilemmákra, ez utóbbi kapcsán szó lesz az önkéntesség motivációinak változásáról is a fiatalok körében. Ezután a formális és informális önkéntességről, valamint az önkéntesség és az önkéntes csoporttagságok kapcsolatáról lesz szó az egyetemisták körében. Majd pedig többváltozós modelljeink eredményeit mutatjuk be, hogy milyen háttérváltozók hatnak az önkéntességre és annak motivációira. Külön részben esik szó a mintáinkban szereplő, környező országok közti különbségekről és az önkéntes turizmusról. Végül arról írunk, mit tehetnek a felsőoktatási intézmények az önkéntesség elősegítésére, és javaslatokat fogalmazunk meg az oktatáspolitika számára.

Kulcsszavak: felsőoktatási hallgatók, önkéntesség és önkéntes csoporttagság, nemzeti önkéntes stratégia, az önkéntesség motivációi

\section{Research findings of the past 10 years on higher education students' volunteering Hajnalka Fényes}

\section{Abstract}

Over the past decade the CHERD-Hungary research centre has monitored the volunteering and voluntary group membership of students in higher education in the historical region of Partium (consisting Eastern Hungary, the Western part of Transylvania (Romania), and Transcarpathia (Ukraine), and for the 2019 survey the sample was extended to Southern Slovakia and Vojvodina (Serbia). Nevertheless, students from Hungary have made up at least the half of each sample of 1,500 to 3,000 people between 2010 and 2019. This paper not only presents research findings of the past ten years

1 Fényes Hajnalka (PhD) közgazdász-szociológus, egyetemi docens, Debreceni Egyetem Szociológia és Szociálpolitika Tanszék 
but also reflects on the first National Volunteer Strategy of Hungary (2012-2020). The 2019 survey includes the impacts of the School Community Service, which was introduced in Hungary in the secondary schools, as the first cohort taking part in this programme entered the higher education in 2016. The introductory section of this paper offers an insight into the main trends of volunteering of students over the period of 2010 and 2019. Then, it addresses important questions with regard to definition of volunteering, such as the dilemmas whether volunteering might be compulsory, or it must be non-compulsory, and whether it may also be beneficial to the volunteers or only to those who are receiving assistance by volunteers. By looking at the individual benefits of volunteers, this paper also analyses the changes in the motivations of students. A particular attention is paid to the discussion about the formal and informal volunteering as well as voluntary group memberships of students. Based on these theoretical discussions the paper provides a detailed research analysis via a multivariate model focusing on the background variables which might affect volunteering and its motivations. By doing this, it also highlights the differences among the regions and countries analysed. Finally, this paper makes an attempt to answer the crucial policy question what higher education institutions could do to promote volunteering.

Keywords: higher education students, volunteering and voluntary group membership, national volunteer strategy, motivations for volunteering

\section{BEVEZETÉS}

Az első Nemzeti Önkéntes Stratégia (2012-2020) kiemelt célja volt, hogy a 18-26 éves korcsoportot jobban be kell vonni az önkéntes tevékenységekbe. Kutatási eredmények szerint 2013 és 2018 között a 18-23 éves korosztályban jelentősen nőtt az önkéntesség (a valamivel idősebbeknél kevésbé). Összességében tehát, a fiatal felnőttek körében emelkedett az önkéntesek aránya, illetve a formális önkéntességben generációváltás zajlott le, megfiatalodott az önkéntesek köre (Bartal 2021).

A CHERD-Hungary kutatóközpont 2010 óta követi nyomon a felsőoktatási hallgatók önkéntességét, 2010-ben csak a Debreceni Egyetem mintáján, 2012-ben Kelet-Magyarország, Erdély partiumi része, és Kárpátalja magyar tannyelvű felsőoktatási intézményeiben, továbbá 2014-ben, valamint 2019-ben a minta már kibővült néhány felvidéki és vajdasági intézménnyel. A minták nagysága 1500-3000 fő között mozgott, melyeknek legalább fele magyarországi diák volt.

Kutatásaink is alátámasztották az egyetemista korosztályban az önkéntesség arányának növekedését. A Debreceni Egyetemen a felsőoktatási tanulmányok alatt valaha önkéntesek aránya 2010-ben még 26, 2012-ben egy bővebb mintán ez az arány már 30, továbbá 2014-ben 37 százalék, míg 2019-ben pedig már 47 százalék volt. 
Azonban, csak a magyarországi almintát nézve, a 2012-es 21 százalékról 2014-re 8 százalékponttal, 2019-re pedig majdnem 17 százalékponttal nőtt az önkéntesek aránya (az országok közti eltérések lehetséges okairól később lesz szó). A 2014 és 2019 közötti magyarországi növekedésben közrejátszhatott, hogy 2016-ben volt az első olyan évfolyam a felsőoktatásban, akik már részt vettek a középiskolai iskolai közösségi szolgálatban.

Összességében nézve, kérdés, hogy ezek az arányok tovább nőnek (például Kanadában a hallgatók 75 százaléka önkéntes), vagy esetleg megáll a növekedés, mint a felnőtt önkéntesek körében, akiknél stagnálás mutatható ki 2017 után, Bartal (2021) eredményei szerint.

További eredményünk, hogy az önkéntes csoporttagságok is növekvő tendenciát mutatnak a vizsgált térségben, de a szervezeti tagság továbbra is elég alacsony. 2019-ben a diákok átlagos szervezeti tagsága nem érte el az egyet. Fontos végül, hogy a trendek mellett az önkéntesség motivációi is változnak (erről később lesz szó).

\section{DEFINÍCIÓS KÉRDÉSEK ÉS A MOTIVÁCIÓK VÁLTOZÁSA A FIATALOK KÖRÉBEN}

Az önkéntesség hagyományos definíciójából két kritériumra reflektálunk, ami különösen érinti a fiatalok önkéntességét. Az egyik, hogy az önkéntesség szabad akaratból, az egyén választása és motivációja alapján végzett tevékenység (azaz nem lehet kötelező vagy kreditekkel elismert), illetve a másik, hogy elsősorban mások (személyek, közösség) javára végzett tevékenység. Mindkét esetben véleményünk szerint tágabb értelmezésre van szükség, mint ahogy az a 2012-2020-ra vonatkozó Nemzeti Önkéntes Stratégiában szerepelt.

Az első esetben (miszerint nem lehet kötelező vagy kreditekkel elismert tevékenység) a kritérium tágítása melletti érveink a következők: Romániában a felsőoktatásban 2014 után az önkéntességet szakmai gyakorlatként is elismerik, és ezzel, adataink szerint számottevően nőtt az „igazi” önkéntesség is. Másik érvünk, hogy az un. „service learning” (közösségi szolgálat) jellegű tárgyak beépítése a tananyagba jelentős kompetencianövelő hatású (lásd. Fényes - Markos 2016). Megjegyezzük, hogy az ilyen kurzusok beépítését a 2012-es Önkéntes Stratégia is támogatja, pedig ez kreditekkel elismert tevékenység. Végül harmadik érvünk a kritérium tágítása mellett, hogy adataink szerint kimutatható az Iskolai Közösségi Szolgálat pozitív hatása az önkéntességre a felsőoktatásban, pedig a stratégia inkább „veszélyforrásként” tekint rá, annak kötelező jellege miatt. Véleményünk szerint mindhárom esetben a fiatalok megismerik az önkéntességet, tapasztalatot szereznek, kedvet csinálhat 
hozzá (persze, csak ha jó a tapasztalat, ami fogadószervezeteken is múlik), de összességében inkább nő a későbbi önkéntesség.

A másik kritérium, amire reflektálunk az, hogy az önkéntesség elsősorban mások (személyek, közösség) javára végzett tevékenység. A tágabb értelemzés melletti érvünk, hogy napjainkban az önkéntesség nemcsak mások számára, hanem az egyénnek is hasznos. Vannak altruista, egoista (self-orientált) és vegyes motivációk. Napjainkban az önkéntesség altruista jellege csökken, nő a szubjektív önértéke, beleértve akár az örömszerzés, a szórakozás szükségletét, motivációját is. A motivációs bázis tehát bővül, és a tradicionális (elsősorban segítő célú) önkéntesség mellett megjelenik az új típusú önkéntesség is a fiatalok körében (ennek típusait lásd később).

Azonban a Nemzeti Önkéntes Stratégia (2012-2020) a professzionális tapasztalatszerzést nem tekinti klasszikus értelemben vett önkéntességnek, pedig kutatásainkban kimutattuk (lásd később), hogy a segítő- és új típusú (például karrierépítő) motiváció együtt járt a diákok körében, tisztán új típusú motiváció nem rajzolódott ki egyik vizsgálatunkban sem. Az új típusú motivációk esetén is fontos volt a diákoknak a másokon segítés, azaz önkéntességük motivációja inkább vegyes.

Az új típusú önkéntesség alábbi, főbb formái és motivációi rajzolódnak ki a fiatalok körében, melyek keveredhetnek is (1. táblázat).

\section{1. táblázat Az új típusú önkéntesség formái az egyetemisták körében}

1. A karrierépitő önkéntesség, melynek motivációi a kulturális tőke (tudás) és hasznos kapcsolatok, munkatapasztalat szerzése, életrajzba való „beírhatóság”. A fejlett országokban a karrierépítő motiváció nem feltétlenül egoista motiváció, ez inkább egy jelzés a munkáltató felé, hogy az illető karriertudatos, és hogy alkalmasabb a feladatra, mint aki nem önkénteskedett. Az életrajzba való „beírhatóság” mint önkéntességi motiváció, térségünkben. 2012-ben még alig volt jellemző, csak napjainkban kezd fontossá válni. A szakirodalom szerint (lásd Handy at al. 2010) az Egyesült Államokban és Kanadában már több évtizedes hagyomány, hogy az állásinterjún figyelembe veszik, az illető volt-e, és hol volt önkéntes, valamint milyen referenciái vannak e téren. Ez nemcsak akkor jelent előnyt, ha kapcsolódott az önkéntesség a tanulmányok jellegéhez, mivel ezekben az országokban köztudott az önkéntesség széleskörű kompetenciafejlesztő hatása. A fiatalok ezen új típusú önkéntességének további jellemzője a tőkekonvertálás. Az önkéntességért ugyan nem jár fizetés, de ahogy láttuk, a fiatalok hasznos kapcsolatokra és tudásra (kulturális tőkére) tesznek szert, amit később gazdasági előnyökre válthatnak. Emellett, ha egy hátrányos helyzetú diák nem kapja meg otthonról ezeket a tőkéket, az önkéntes munkával kompenzálhatja hátrányait. 
2. A kapcsolatépítő önkéntesség és motiváció, mely nemcsak a karrierépítéshez hasznos kapcsolatokat jelenti, hanem barátok és egyéb ismerősök szerzését is.

3. A posztmodern önkéntesség, ahol maga a részvétel a fontos, jó másokkal együtt lenni, identitást ad, például a zöld- és békeszervezetekben való részvétel.

4. A szabadidős önkéntesség lehet például kulturális és sportszervezetekben, eseményeken (például fesztiválokon), de ezt csak akkor tekinthetjük önkéntességnek, ha mások javára is végez munkát valaki a tevékenység során.

5. A tanulmányok jellegéhez kapcsolódó önkéntesség egy külön típus lehet, mely kiegészíti az egyetemi képzést és gyakorlati tudást nyújt. A tanulmányok jellegéhez való kapcsolódás és a karrierépítő motiváció nem feltétlenül esik egybe, mivel lehet, hogy az önkéntesség csak a téves pályaválasztást korrigálja, és más területen önkéntes a diák, mint amit tanul. Ekkor az önkéntesség során szerzett tapasztalatot, még ha az nem is függ össze a tanulmányaival, hasznosítani tudja a karrierépítés során.

6. A forgóajtós-önkéntesség külön típus, szakirodalmilag jól kidolgozott és megalapozott (lásd: Hustinx 2001). Ennek során a diákok kipróbálják magukat több munkáltatónál, ami segíti a karriertervezést, és a jelenség hátterében a fiatalokra jellemző un. kísérletező szocializáció áll.

Forrás: Fényes et al. (2021) alapján

Összegzésképpen, ha csoportosítani akarjuk a motivációkat, két típus rajzolódik ki (2. táblázat).

\section{2. táblázat Az önkéntesség motivációinak két típusa a fiatalok körében}

\begin{tabular}{|c|c|}
\hline Az önérdekű és szakmai tapasztalatszerző motivációk & Az altruista motivációk \\
\hline $\begin{array}{l}\text { - } \quad \text { kapcsolatépítés, hasonló érdeklődésű körűekkel } \\
\text { való találkozás; } \\
\text { - } \quad \text { a szabadidő hasznos eltöltése, sport és kulturális } \\
\text { aktivitások tanulása és végzése; } \\
\text { - } \quad \text { információszerzés, készségfejlesztés, könnyebb } \\
\text { munkához jutás; }\end{array}$ & $\begin{array}{l}\text { - az önkéntesség hasznos legyen a } \\
\text { társadalom számára; } \\
\text { - másokért való tenni akarás; } \\
\text { - } \quad \text { a saját és mások jogainak és } \\
\text { érdekeinek védelme; }\end{array}$ \\
\hline
\end{tabular}

Forrás: Fényes et al. (2021) alapján

Empirikus eredményeik szerint (lásd lent), ahogy már írtuk, a tradicionális, segítő célú önkéntesek mellett megjelentek az új típusú önkéntesek is a hallgatók körében, de nekik is fontos volt a segítő szándék. 2012-es vizsgálati eredményeink (Fényes - Pusztai 2012a) szerint három klaszter rajzolódott ki a motivációk mentén a tágabb mintánkban:

- a tradicionális,

- $\quad$ a vegyes, illetve

- $\quad$ egy olyan vegyes motivációs csoport, ahol az életrajzba való „beírhatóság” még nem volt fontos szempont. 
A 2019-es adatok viszont már azt mutatták, hogy csak két klaszter van: a csak segítő célú, és a vegyes motivációjú csoport, azaz feltehetőleg az életrajzba való „beírhatóság” időben egyre inkább fontossá vált a diákok körében a mi térségünkben is (Fényes et al. 2021).

A 2014-es vizsgálatunkban (Fényes 2015a; Fényes 2019), 2012 és 2019-hez képest egy szélesebb skálán, 21 itemmel mértük az önkéntesség motivációit (a Clary-féle nemzetközi skálát adaptáltuk a fiatalokra). A faktorelemzés eredményeit lásd a 3. táblázatban.

3. táblázat: Az önkéntesség motivációs faktorai 2014-ben

\begin{tabular}{|c|c|c|}
\hline $\begin{array}{c}\text { Vegyes } \\
\text { (segítő és egyben új típusú) } \\
\text { motivációk }\end{array}$ & $\begin{array}{c}\text { Saját pszichológiai fejlődési } \\
\text { motivációk }\end{array}$ & $\begin{array}{l}\text { Posztmodern önkéntességi } \\
\text { motivációk }\end{array}$ \\
\hline $\begin{array}{c}\text { a másokon való segítés } \\
\text { fontossága mellett a szabadidő } \\
\text { hasznos eltöltése; } \\
\text { új ismeretek szerzése; } \\
\text { szakmai fejlődés; } \\
\text { készségek gyakorlása; } \\
\text { új ismerősök, barátok szerzése; } \\
\text { szakmai kapcsolatok szerzése } \\
\text { és } \\
\text { a munkatapasztalat; }\end{array}$ & $\begin{array}{c}\text { fontos, hogy az illető jobban } \\
\text { érezze magát az önkéntesség } \\
\text { által; } \\
\text { változtatni akart a világon; } \\
\text { hasznosnak akarja érezni } \\
\text { magát; } \\
\text { felül akar emelkedni saját } \\
\text { problémáin; } \\
\text { szeretné, hogy valahol } \\
\text { elismerjék; } \\
\text { másként látni a világot; } \\
\text { megismerjen, megértsen } \\
\text { másokat; }\end{array}$ & $\begin{array}{c}\text { fontos a nyelvtanulás; } \\
\text { az új kultúrák megismerése; } \\
\text { a környezetvédelem a globális } \\
\text { problémák megoldása; } \\
\text { a hagyományőrzés és } \\
\text { a kulturális értékek védelme; }\end{array}$ \\
\hline
\end{tabular}

Forrás: Fényes (2015a) és Fényes (2019) alapján

A 21 motiváció mentén klaszterelemzést is végzetünk és három karakteres csoport rajzolódott ki: a karrierépítő és egyben posztmodern csoport, a segítő és egyben új típusú motivációs csoport, és végül egy harmadik csoport, amit majdnem minden motivált, kivéve az, hogy a család vagy a barátok voltak önkéntesek, illetve, hogy be lehessen írni az önéletrajzba (Bocsi et al.2017).

\section{FORMÁLIS ÉS INFORMÁLIS ÖNKÉNTESSÉG, AZ ÖNKÉNTES CSOPORTTAGSÁGOK ÉS}

\section{AZ ÖNKÉNTESSÉG}

A szakirodalomban az önkéntesség egyik kritériuma, hogy általában szervezett keretek között zajlik. Azonban a fiatalokra egyre inkább jellemző az alkalmi és projekt-típusú önkéntesség. A 
korábban bemutatott új típusú önkéntesség rövidebb elkötelezettséggel jár, a fiatalok rugalmas, kevésbé állandó szervezeti keretek között végeznek önkéntes tevékenységet.

2010-ben a Debreceni Egyetem hallgatóinak 6-7 százaléka volt csak rendszeres, míg 20 százalékuk alkalmi önkéntes (Fényes 2015b). Bartal (2021) szerint is a fiatalokra jellemző az epizodikus, vagy akcionalista önkéntesség (évenként egyszeri alkalommal, fesztiválokon, vagy például a „72 óra kompromisszumok nélkül” - akció).

A 2014-es adataink szerint a vizsgált térségben az összes diák közül az alkalmi (évente egyszer) önkénteskedők aránya 21 százalék, míg a rendszeres (havonta vagy hetente) önkéntesek valamivel kevesebben voltak (16 százalék). Ezek az arányok 2019-re nőttek - 28,5 százalék, illetve 18,3 százalék -, de a tendencia megmaradt. Amennyiben csak a magyarországi adatokat nézzük, a rendszeres (havonta, hetente) önkéntesek aránya jóval alatta marad (10-11 százalék) a térségi átlagnak mindkét időpontban, azaz nálunk még erősebben jellemző az alkalmi önkéntesség.

A 2012 és 2019 közötti kutatásainkban nem kérdeztünk rá arra, hogy a hallgatók az egyetemi évek alatt az önkéntességet szervezeteknél vagy egyéb formában végzik-e, viszont mértük a hallgatók önkéntes (formális és informális) csoporttagságait és külön azt, hogy voltak-e önkéntesek a felsőoktatási tanulmányaik során. Eredményeink szerint az önkéntes csoporttagságok és önkéntes aktivitások nem mindig estek egybe.

A 2019-es eredmények szerint a diákok átlagosan alig egy $(0,88)$ csoportban/szervezetben vettek részt, és ahogy láttuk 46,8 százalékuk volt már önkéntes felsőoktatási tanulmányai során (Bocsi et al. 2020). Az elmúlt tíz évben a leggyakoribb csoporttagságok (ahol a diákok több mint 10 százaléka részt vett) a vallási, a sport és a kulturális csoporttagságok voltak. 2019re - a korábbi 2010-es eredményeinkhez képest (lásd. Fényes -Pusztai 2012b; Fényes 2015b; Pusztai 2017) -, majdnem minden szervezetben nőtt a diákok részvételi aránya. Kiugróan emelkedett a vallási szervezetekben (12-ről 24 százalékra), az ifjúsági érdekképviseleti szervezetekben (6-ról 11 százalékra), de az önkéntes (5,2-ről 13,2 százalékra) és civil szervezetekben is (3,4-ről 10,8 százalékra).

A csoporttagságok esetén az önkéntes aktivitás előfordulása leggyakoribb a jótékonysági és karitatív szervezeti tagoknál (87 százalékban), a civil szervezeti tagoknál (75 százalékban) valamint a politikai szervezetek tagjainál (74 százalék) míg legalacsonyabb a sportszervezeti 
tagoknál (53 százalék) volt. Összességében tehát csoporttagság esetén 50 százalék feletti az önkéntesség esélye (Bocsi et al. 2020)

Számos kutatás (például Milem - Berger 1999) kimutatta, hogy az intézményhez kötődő önkéntesség és az önkéntes csoporttagság segíti az integrációt a campusba, amely által csökken a lemorzsolódás, és nő a tanulmányi eredményesség.

A 2014-ös adataink szerint, a szakirodalommal összhangban, a civil aktivitás (az önkéntesség és szervezeti tagságok összevont mutatója) nem csökkentette az intézményi integráltságot, nem vont ki a campusból, és végső soron nem növelte a lemorzsolódási esélyt sem, egyéb változók kontrollja mellett (Fényes et al. 2018). 2019-es adatok szerint az önkéntesség növelte a tanulmányok befejezése melletti kitartást (a perzisztenciát), azaz csökkentette a lemorzsolódás kockázatát. Az önkéntes csoporttagságok pedig szintén nem vontak ki a campusból, igaz nem is növelték a bennmaradás esélyét (Pusztai et al. 2021).

\section{HAT AZ ÖNKÉNTESSÉGRE, ÉS ANNAK MOTIVÁCIÓIRA?}

2010-ben a Debreceni Egyetemen a lányokra inkább a tradicionális típusú önkéntesség volt a jellemző (segítő szolgálat, karitatív munka, önkéntes szervezeti tagság), míg a fiúk körében viszont népszerű volt a sport és a kultúra, illetve az ezekhez kapcsolódó önkéntesség, de a civil szervezetekben, természetvédő csoportokban, politikai szervezetekben is gyakrabban vettek részt, mint a lányok. Azonban általában nézve, 2010-ben az önkéntes tevékenység esélyére nem hatott a diákok neme, sőt a kora sem (Fényes 2015b; Fényes - Pusztai 2012b).

A 4. táblázatban látható, hogy a 2010 és 2019 közötti méréseinkben milyen tényezők hatottak pozitívan az önkéntesség esélyére (Bocsi - Fényes 2012; Fényes 2015a; Bocsi et al. 2020). Az önkéntes csoporttagságokra pedig pozitív hatással volt 2019-ben, ha valaki férfi, ha gyakoribb templomba járó, ha a szülőkkel lazább és az oktatókkal szorosabb a kapcsolata, a jobb tanulmányi eredmények és a fizetett munkavégzés (Bocsi et al. 2020).

További kérdés, hogy milyen háttérváltozók hatnak az önkéntesség motivációira a fiatalok körében. Mind 2012-ben, mind pedig 2014-ben kimutattuk, hogy a vallásos diákokra nem jellemzőbb a tradicionális, csak segítő célú önkéntesség, és a vallásos fiatalok motivációja is inkább vegyes (Fényes -Pusztai 2012a; Fényes 2015a). 2014-ben a vegyes (segítő és egyben új típusú) motiváció a vallásosabb diákok mellett inkább a nőkre, az idősebb diákokra, a 
városiakra és a rosszabb anyagi helyzetű családok gyermekeire, míg a posztmodern önkéntesség a fiatalabb diákokra és a romániai és ukrajnai almintára, és végül a pszichológiai fejlődési motiváció pedig leginkább a lányokra volt inkább a jellemző (Fényes 2015a).

4. táblázat Az önkéntesség esélyét növelö tényezök az egyetemisták körében

\begin{tabular}{|c|c|c|}
\hline 2010 & 2014 & 2019 \\
\hline $\begin{array}{c}\text { az anya magasabb } \\
\text { iskolázottsága; } \\
\text { a diák saját jobb anyagi } \\
\text { helyzete; } \\
\text { az egyház tanításait követő } \\
\text { vallásosság; } \\
\text { segítő szakma tanulása; }\end{array}$ & $\begin{array}{c}\text { a vallásos kisközösségi tagság; } \\
\text { az idősebb életkor; } \\
\text { a városi származás. } \\
\text { a szülőkkel való lazább és az } \\
\text { oktatókkal való szorosabb } \\
\text { kapcsolat; }\end{array}$ & $\begin{array}{c}\text { a gyakoribb templomba járás; } \\
\text { a szülőkkel való lazább és az } \\
\text { oktatókkal való szorosabb } \\
\text { kapcsolat; } \\
\text { a jobb tanulmányi eredmények; } \\
\text { a fizetett munkavégzés; } \\
\text { a külső (egyetemen kívüli) } \\
\text { barátokkal való szorosabb } \\
\text { kapcsolat; } \\
\text { a nem gazdaságtudományi } \\
\text { területen folytatott } \\
\text { tanulmányok; }\end{array}$ \\
\hline
\end{tabular}

Forrás: Fényes - Pusztai (2012b), Fényes (2015a és b) és Bocsi et al. (2020) alapján

A 2019-es adatok szerint a vallásos diákokra ekkor sem volt jellemzőbb a tradicionális, csak segítő célú önkéntesség. Viszont a diák rosszabb saját objektív anyagi helyzete, a szülőkkel, az oktatókkal és a külső (nem egyetemi) barátokkal való szorosabb kapcsolat növelte a vegyes (karrierépítő és egyben segítő) motivációjú önkéntes csoportba tartozás esélyét a csak segítőtípusú csoporttal szemben.

Fontos eredménynek tartjuk (Fényes et al.2021), hogy akiknek jobb volt az oktatókkal való kapcsolata, náluk nagyobb eséllyel kapcsolódott az önkéntesség a tanulmányok jellegéhez, és ugyanez jellemző a segítő szakmákat tanulókra (pl. a pedagógus hallgatókra), így elsősorban ők tudják majd kihasználni az önkéntességben rejlő karrierépítési lehetőséget (szemben a reál és a gazdasági területeken tanulókkal).

\section{A MINTÁINKBAN SZEREPLŐ, KÖRNYEZŐ ORSZÁGOK KÖZTI KÜLÖNBSÉGEK}

Kutatásainkban a kis elemszámok miatt a szerbiai és szlovákiai adatokat most nem mutatjuk be, hanem csak három térségben, Kelet-Magyarországon, Románia partiumi részén és Ukrajnán belül Kárpátalján mért adatainkat hasonlítjuk össze. 
Látható (5. táblázat), hogy 2012-ben a romániai almintában volt a legmagasabb, míg a magyarországi almintában a legalacsonyabb az önkéntesek aránya, illetve később is a romániai és ukrajnai almintában szignifikánsan többen voltak önkéntesek, mint Magyarországon (Fényes -Pusztai 2012a; Fényes 2015a; Bocsi et al. 2020). Ennek fő oka lehet, ahogy már említettük, hogy Romániában 2014 óta szakmai gyakorlatként is elismerik az önkéntességet, ami növelhette az önkéntesség arányát.

5. táblázat Az önkéntesség országonkénti aránya az egyetemisták körében, 2012 és 2019 között

\begin{tabular}{|l|c|c|c|}
\hline & $\mathbf{2 0 1 2}$ & $\mathbf{2 0 1 4}$ & $\mathbf{2 0 1 9}$ \\
\hline magyarországi alminta & $21 \%$ & $29 \%$ & $37,8 \%$ \\
\hline ukrajnai alminta & $31 \%$ & $55 \%$ & $42,8 \%$ \\
\hline romániai alminta & $39 \%$ & $56 \%$ & $60 \%$ \\
\hline
\end{tabular}

Forrás: Fényes -Pusztai (2012a), Fényes (2015a) és Bocsi et al. (2020) alapján

Az önkéntes csoporttagságokat nézve ez 2014-ben és 2019-ben leggyakoribb az ukrajnai almintában volt, míg a magyarországi almintában mutatkozott a legalacsonyabbnak (Pusztai 2017; Bocsiet al. 2020). Ennek hátterében az állhat, hogy a kisebbségi helyzetben levő hallgatók aránya az ukrajnai almintában a legmagasabb, míg a magyarországi almintában a legalacsonyabb volt, és Pusztai (2017) eredményei szerint a kisebbségi lét növeli az önkéntes csoporttagságok elfordulásának esélyét. Másik magyarázat lehet, hogy Ukrajnában a narancsos forradalom után egy felfutás volt a civil mozgalmakban és a civil aktivitásban.

Amennyiben az önkéntesség motivációit vizsgáljuk, azt láthatjuk, hogy 2012-ben a romániai almintában vegyesek a motivációk, a magyarországi és ukrajnai almintára pedig a csak segítő célú önkéntesség és a vegyes motivációk (az életrajzba való beírhatóság nélkül) voltak fontosak (Fényes-Pusztai 2012a).

2014-ben mindhárom országban a vegyes motivációk dominálnak, de a karrierépítő és egyben posztmodern motivációk inkább a romániai alminta sajátossága volt. A család és barátok önkéntessége és az „életrajzba való beírás” motivációs tényezőkön kívül minden más motivációs tényező az ukrajnai almintára volt jellemző (Bocsi et al. 2017). Ugyanakkor 2019ben kimutattuk, hogy az ukrajnai almintában az önkéntesség csak kevéssé kapcsolódott a tanulmányok jellegéhez, feltehetőleg a megfelelő lehetőségek hiánya miatt. 
Az önkéntesség egy speciális esete az önkéntes turizmus, ami térségünkben még viszonylag új jelenség, de a fejlettebb országokra jellemző, hogy a diákok a középiskola után kihagynak egy évet és külföldön önkénteskednek. Silló (2016. 2018) a Csiki-medencében készített interjúkat külföldi önkéntesekkel, és azt is vizsgálta, hogy miben különböznek a hazai (erdélyi) önkéntesektől, akár a motivációkat, akár egyéb jellemzőket tekintünk. A külföldiek motivációi voltak többek közt, hogy nyelvet tanulnak, megismerjenek új kultúrákat, kipróbálják magukat egyes területeken (ezzel segítve a pályaválasztást), emellett a munkatapasztalat-szerzést beírhatják önéletrajzukba.

\section{MIT TEHETNEK A FELSŐOKTATÁSI INTÉZMÉNYEK? - POLICY JAVASLATOK}

Köztudott az önkéntesség pozitív multiplex hatása mind a tevékenységben résztvevőkre, mind a célcsoportra, mind a külső környezetre. Mindezek fényében javasoljuk, hogy az egyetemek - hasonlóan a többi fejlett országhoz - nálunk is támogassák a hallgatók önkéntességét, és ezt akár szervezett formában, kreditekkel elismerve tegyék. Fenti adataink jól bizonyították, hogy például Romániában, ahol az önkéntességet 2014 óta elismerik szakmai gyakorlatként, jelentősen nőtt az önkéntesség aránya az egyetemista fiatalok körében. Emellett a „servicelearning” típusú tárgyak curriculumba való beillesztése pozitív hatással lehet a hallgatók önkéntességére és civil szervezeti tagságára is. Amennyiben a végzett tevékenység területe kapcsolódik a tanulmányok jellegéhez, az segít a szakmai kapcsolatok kiépítésében, továbbá a szakismeretek gyakorlatban való elsajátításában is, és jól kiegészíti az elméleti egyetemi kurzusokat.

Szükséges lenne karrierirodákat is működtetni az egyes karokon, tanszékeken, ahol a szakmához kötődő, tanulás mellett végezhető önkéntes és fizetett munkalehetőségeket kínálnak a hallgatók számára. Emellett jó lenne, ha az önkéntesség koordinálására, a tapasztalatok „átbeszélésére” az intézmények külön szakembert alkalmazhatnának. Láthattuk, hogy a karrierépítés elemei fontosak az egyetemistáknak - ezekre építve is lehetne őket motiválni a szervezetekbe való bekapcsolódásra.

Az egyetemen belüli és kívüli csoporttagságokra tekinthetünk úgy is, mint az önkéntesség potenciális színtereire, de ahogy láttuk, kutatási eredményeink szerint a diákok szervezeti részvétele még alacsony a vizsgált térségben. Ennek ösztönzésére az egyetemek felkínálhatnának helyszínt, például a vallásos ifjúsági szervezeteknek, emellett támogathatják 
az aktív szabadidős sportolásban érdekelt amatőr hallgatók részételét az egyetemi csapatokban, így a sportszervezeti tagságnak jobban érvényesülne az egyetemi életbe integráló szerepe. Emellett a kulturális (múvészeti) csoportok létrehozását is fontos lenne népszerúsíteni, melyek a szociális kompetenciák és a kreativitás fejlesztésén túl az elmaradt kulturális tőke pótlására is alkalmasak, akár tanulmányi kreditekért elvégzendő, szabadon választható tantárgyak formájában is.

Fontos figyelembe venni emellett, hogy eredményeink szerint mely hallgatói csoportok vesznek részt kevésbé a civil aktivitásokban, illetve hol nem érvényesülnek még eléggé a karrierépítő célok az önkéntes munka során, és körükben kiemelten kellene népszerűsíteni az önkéntességet és a szervezeti részvételt. Továbbá eredményeink szerint mind az önkéntesség, mind az önkéntes csoporttagság gyakoribb volt azon hallgatóknál, akiknek az oktatókkal szorosabb a kapcsolata, tehát az oktatók közremúködését is ösztönözni kell.

\section{IRODALOM}

Bartal Anna Mária (2021): Régi reflexek és új kihívások - az első Nemzeti Önkéntes Stratégián túl, a másodikon innen. Civil Szemle, 17(1) pp. 41-61.

Bocsi Veronika - Fényes Hajnalka (2012): Values and the Motivations of Higher Education Students' Volunteering in a Borderland Central Eastern European Region. In: Pusztai G. - Hatos A. - Ceglédi T. (eds.) Third mission of Higher Education in a Cross-Border Region. Debrecen: CHERD-Hungary, University of Debrecen, pp. 160-179.

Bocsi Veronika - Fényes Hajnalka - Markos Valéria (2017): Motives of Volunteering and Values of Work among Higher Education Students Citizenship Social and Economics Education, 16(2) pp. 117-131. https://doi.org/10.1177/2047173417717061

Bocsi Veronika - Fényes Hajnalka - Markos Valéria (2020): Civic Engagement of Higher Education Students in a Central and Eastern European Region. The New Educational Review, 62(4) pp. 80-90. DOI: 10.15804/tner.2020.62.4.07

Fényes Hajnalka (2015a): Effect of Religiosity on Volunteering and on the Types of Volunteering among Higher Education Students in a Cross-Border Central-Easten European Region. Acta Universitatis Sapientiae. Social Analyses, 5(2) pp. 181-203.

Fényes Hajnalka (2015b): Önkéntesség és új típusú önkéntesség a felsőoktatási hallgatók körében. Debrecen: Debreceni Egyetemi Kiadó

Fényes, Hajnalka (2019): A felsőoktatási továbbtanulás, a tanulás melletti fizetett és önkéntes munka, mint humántőke-befektetés. In: Fényes H. - Mohácsi M.: Munkaerőpiac és emberi tôke. Elmélet és gyakorlat. Debrecen: Debreceni Egyetemi Kiadó, pp: 89-122.

Fényes Hajnalka - Pusztai Gabriella (2012a): Religiosity and Volunteering among Higher Education Students in the Partium Region. In: Györgyi Z. - Nagy Z. (eds.): Students in a Cross-Border Region. Higher Education for Regional Social Cohesion. Nagyvárad (Oradea, Románia): University of Oradea Press, pp: 147-167. 
Fényes Hajnalka - Pusztai Gabriella (2012b): Volunteering among Higher Education Students, Focusing on the Micro-level Factors, Journal of Social Research and Policy, 3(1), pp: 73-96.

Fényes Hajnalka -Markos Valéria (2016): Az intézményi környezet hatása az önkéntességre. In: Pusztai G. - Bocsi V. - Ceglédi T. (szerk.): A felsőoktatás (hozzáadott) értéke. Közelítések az intézményi hozzájárulás empirikus megragadásához. Nagyvárad - Budapest: Partium; PPS, Új Mandátum, pp. 248261.

Fényes Hajnalka -Markos Valéria, Pusztai Gabriella (2018): A felsőoktatási hallgatók civil aktivitása és a lemorzsolódási esélyük összefüggései. Metszetek, 7(3) pp. 141-156. DOI: 10.18392/metsz/2018/3/6 Fényes Hajnalka - Markos Valéria - Mohácsi Márta (2021): Volunteering among Higher Education Students as Part of Individual Career Management Corvinus Journal of Sociology and Social Policy (megjelenés alatt)

Handy, Femida - Cnaan, Ram A. - Hustinx, Lesley - Kang, Chulhee - Brudney, Jeffrey L. - HaskiLeventhal, Debbie - Holmes, Kristen - Meijs, Lucas C. -Pessi, Anne B. - Ranade, Bhagyashree -Yamauchi, Naoto - Zrinscak, Sinisa (2010): A Cross-Cultural Examination of Student Volunteering: Is It All About Résumé Building? Nonprofit and Voluntary Sector Quarterly, 39(3), pp. 498 - 523. https://doi.org/10.1177/0899764009344353

Hustinx, Lesley (2001): Individualization and New Styles of Youth Volunteering: an Empirical Exploration. Voluntary Action, 3(2), pp. 57- 76.

Milem, Jeffrey F. - Berger, Joseph B. (1997): A modified model of college student persistence: Exploring the relationship between Astin's theory of involvement and Tinto's theory of student departure. Journal of College Student Development, 38(4) pp. 387-400.

Pusztai Gabriella (2017): Hallgatók civil közösségi részvétele öt ország tizenhárom felsőoktatási intézményében. Kultúra és Közösség, 8(3) pp. 95-108.

Pusztai Gabriella - Fényes Hajnalka - Markos Valéria (2021): The Effect of Volunteering and Voluntary Group Membership on Students' Persistence. Voluntas (megjelenés alatt)

Silló Ágota (2016): Az önkéntesség modern formái. In: Berger Viktor (szerk.): Útközben: Az I. Demográfia és Szociológia Doktoranduszkonferencia anyagai. Pécs: Pécsi Tudományegyetem Bölcsészettudományi Kar Demográfia és Szociológia Doktori Iskola, pp. 71-81.

Silló Ágota (2018): International Volunteers as Strangers in Szeklerland. Acta Universitatis Sapientiae. Social Analyses, 8(1) pp. 5-21. https://doi.org/10.2478/aussoc-20180001 